\title{
Enrolling Citizens as Informed Consumers in Quasi-markets
}

Ranerup, Agneta; Zinner Henriksen, Helle

Document Version

Final published version

Published in:

Information Technology and People

DOI:

10.1108/ITP-07-2017-0232

Publication date:

2019

License

CC BY

Citation for published version (APA):

Ranerup, A., \& Zinner Henriksen, H. (2019). Enrolling Citizens as Informed Consumers in Quasi-markets. Information Technology and People, 32(6), 1517-1535. https://doi.org/10.1108/ITP-07-2017-0232

Link to publication in CBS Research Portal

\section{General rights}

Copyright and moral rights for the publications made accessible in the public portal are retained by the authors and/or other copyright owners and it is a condition of accessing publications that users recognise and abide by the legal requirements associated with these rights.

Take down policy

If you believe that this document breaches copyright please contact us (research.lib@cbs.dk) providing details, and we will remove access to the work immediately and investigate your claim. 


\title{
Enrolling citizens as informed consumers in quasi-markets
}

\author{
Agneta Ranerup \\ Department of Applied Information Technology, \\ University of Gothenburg, Gothenburg, Sweden, and \\ Helle Zinner Henriksen \\ Department of Digitalization, \\ Copenhagen Business School (CBS), Frederiksberg, Denmark
}

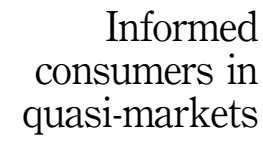

1517

Received 24 July 2017

Revised 8 June 2018

13 December 2018

Accepted 14 December 2018

\begin{abstract}
Purpose - Many countries today, especially in Europe, provide publicly funded public services in quasi-markets. As these markets commercialize, agencies of various types are providing technologies that support citizens' choice of services. Citizens' use of technologies for service provision is studied as e-government under labels of channel management, e-service uptake or adoption. In contrast, by using actor-network theory (ANT), the purpose of this paper is to focus on the marketing devices that are used to enroll citizens to choose technologies in a context with large penetration of quasi-market arrangements.

Design/methodology/approach - Based on a Swedish case study, this paper uses qualitative data from 11 occurrences of technologies to support citizens' choice ("market devices") in education, healthcare and public pension in an analysis of the means taken ("marketing devices") to increase their use. The study formulates a tentative typology of these devices.

Findings - The marketing devices are intended to attract citizens' attention to the possibility of choice (e.g. catalogs, postcards and commercials), invite interaction (e.g. various social media platforms), improve the technological support in line with user needs (e.g. user participation in development), increase visibility of technological support (e.g. search optimization) or directly connect citizens to technological support (e.g. via links).

Originality/value - The paper contributes to e-government research through a typology of means taken to increase citizens' technology use based on selected concepts from ANT, and to a discussion of technologies and humans.
\end{abstract}

Keywords Decision making, E-government, Adoption, Case study, Consumer behaviour,

Actor-network theory, Web services

Paper type Research paper

\section{Introduction}

The term "more government for less money" (Osborne and Gaebler, 1992) has resulted in services that had formerly been provided only in a monopolistic fashion by public actors now being offered in a market. This move has led to the emergence of quasi-markets in which competing public and private actors offer publicly funded services (Le Grand, 2009). The movement has spread into new areas (e.g. the Australian National Disability Insurance Scheme, cf. Carey et al., 2018). As a result, market mechanisms guide players' behavior in an increasingly competitive environment, where service providers seek to engage citizens in their service offerings. The trend of making citizens more active in their interaction with public service providers through their use of technologies is well known in the research domains of e-government and e-commerce.

(c) Agneta Ranerup and Helle Zinner Henriksen. Published by Emerald Publishing Limited. This article is published under the Creative Commons Attribution (CC BY 4.0) licence. Anyone may reproduce, distribute, translate and create derivative works of this article (for both commercial \& non-commercial purposes), subject to full attribution to the original publication and authors. The full terms of this licence may be seen at http://creativecommons.org/licences/by/4.0/legalcode

The authors acknowledge funding from The Swedish Foundation for Humanities and Social Sciences (Managing Overflow) and the Swedish Research Council (2013-00861).

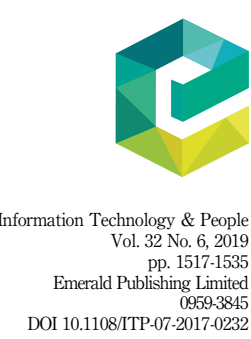


Examples of e-government research include e-service uptake (Carter et al., 2016; Gilbert et al., 2004; Mensah, 2018), e-service provision (Kernaghan, 2013) and channel management (Teerling and Pieterson, 2011). Channel management research focuses on the instruments and activities governments use to populate their channels such as internet self-service, e-mail, phone and front desk encounters (Teerling and Pieterson, 2011). E-service provision can influence citizens' use of services by directing and redirecting users via television commercials, targeted mail promotions and posters that inform citizens of services and recommend channels (Kernaghan, 2013).

Research on influencing citizens as technology users of a more general character is framed as "adoption" (Gilbert et al., 2004; Carter et al., 2016). A recent literature review of online services in the literature on the public sector highlights the dominance of technological deterministic modes of explanation such as the TAM and UTAUT models (Gupta et al., 2016). Unlike the actor-network theory (ANT) research tradition (Callon, 1986; Hanseth et al., 2004; Latour, 1987), this research stream often considers the roles of adopters and technologies as clearly defined and quantifiable (James, 2014).

In the e-commerce research stream, there is now greater attention to the customization of consumer services, such as in the travel and tourism industry where consumers redefine accountability by co-producing content, via ratings and rankings (Scott and Orlikowski, 2012). Platforms such as Booking.com, Expedia and Trip Advisor use online communities and websites to promote their services and to support informed choice by involving suppliers and consumers of services. This trend is also observable in public service provision where public agencies, public-private partnerships (PPPs) and private companies provide sometimes competing (Karpik, 2010) technological support for choice, including comparisons, ratings and other user-generated content (Gobby, 2016; Graham, 2016; Wilkins, 2012). The introduction of often web-based technologies can be viewed as a translation process (Callon, 1986) in which material devices and activities are central actors in the construction of markets for public services (Johansson Krafve, 2015; Zuiderent-Jerak and van Egmond, 2015).

In contrast to the perspectives on increasing citizens' technology use (Carter et al., 2016; Kernaghan, 2013; Teerling and Pieterson, 2011), the role of technological support for choice is now often enacted to stimulate citizens to operate in a market of public services. This paper explores the devices and other activities (Law and Ruppert, 2013) used to engage citizens in public service provider plans in general, and as users of technologies to support choice in particular (Gobby, 2016; Ranerup, 2007; Wilkins, 2012). These technologies might provide information about the rights of choice as well as detailed information about the available public services. In this way, they all contribute to transforming citizens from users to consumers of public services (Clarke et al., 2007).

In this new role, the citizen-consumer must have the technological sophistication to navigate a competitive environment that the public sector had traditionally monopolized. The issue of whether citizens can make informed choices of services under these new conditions is controversial (Fotaki et al, 2008; Nordgren, 2010). The controversy arises because citizen choice challenges a fundamental understanding of the relationship between the citizen and the welfare state (Clarke et al, 2007). There is also the question of whether citizens are interested in being consumers of welfare services and, more importantly, if they are capable of making informed choices given the often limited information on the alternatives (Fotaki et al, 2008; Johansson Krafve, 2015; Nordgren, 2010).

This paper examines the shaping of citizen-consumers through the ANT, thereby contributing to the discussion of the role of technologies and humans (Callon, 1986; Mwenya and Brown, 2017). We explore how public, semi-private and private actors use market devices in the form of technologies to support citizens' choice, and promote their use through marketing devices and other activities. The article describes the stage of interessement in 
the four-stage ANT process (Callon, 1986), and thus in the negotiations that transform citizens into consumers through their choice of services supported by technology use. Three quasi-market areas in Sweden - education, healthcare and public pension investing - serve as the empirical foundation for the study.

This study answers the following research question:

$R Q 1$. How are technological marketing devices used to shape citizen-consumers in quasi-markets?

The next section explains how e-government research has applied ANT and presents the theoretical background. We then describe our data collection procedure and analysis. The section thereafter presents a mapping of the actor network of the forming of quasi-markets including the translation of citizens into consumers in the three areas of education, healthcare and pension. The final sections present our contribution in the form of a tentative typology of marketing devices directed to citizens in addition to our conclusions and recommendations for further studies.

\section{Theoretical background}

\subsection{ANT in e-government and beyond}

ANT (Callon, 1986; Latour, 1987) in general and a stream of research in ANT in particular (Callon, 1998; Callon and Muniesa, 2005) outline a theoretical perspective that can be used to study the roles of technologies and humans in programs with the intention of making citizens into calculating consumers ("citizen-consumers") in quasi-markets. Perspectives of ANT have inspired studies in e-government research over the last 15 years. Fornazin and Joia (2016) summarize ANT's contributions by emphasizing the flexibility of observation that might involve multiple actors, along with a dominant focus on longitudinal approaches. One often-cited e-government study that uses ANT is Heeks and Stanforth's (2007) study of project trajectories. Their study draws an important distinction between a static view of power and a more dynamic "power to." However, studies of translation processes and their different phases (problematization, interessement, enrollment and mobilization), including a qualified view of technological and human actors are the most common uses of ANT in e-government research (Fornazin and Joia, 2016). Recent examples are Söderström's (2016) study of the introduction of public- sector eIIs and Cordella and Hesse's (2015) study of interactions and dynamics of an e-government project in Kerala, India.

In his overview of Callon's research, Cochoy (2014) traced the development from the most famous paper (Callon, 1986), describing processes of translation and introducing the notion of symmetry between human and technological actors. Since 1998, Callon has been interested in the roles of humans, technologies and devices in markets (Callon, 1998, 2016; Callon and Muniesa, 2005). The use of technology as representations of market devices can be viewed as a means to install calculative practices (Callon and Muniesa, 2005) or to support informed choice. Studies of technologies in markets have addressed areas such as finance (MacKenzie, 2009; Roscoe, 2013), environmental policy (MacKenzie, 2009), fuel retailing (Azimont and Araujo, 2010) and online dating (Roscoe and Chillas, 2014).

Studies of the role of technology in quasi-markets or welfare markets, while less common, focus on technologies that support, for example, informed choice in education (Gobby, 2016; Wilkins, 2012) and in public pension investing (Ranerup, 2007), or comparisons of service types and business models (Ranerup et al., 2016). In these studies, technological devices are analyzed and evaluated from the perspective of enabling calculative behaviors (Callon and Muniesa, 2005) or from the general perspectives of hybridity (Ranerup, 2007). Further, a study of the materiality of regulating welfare markets and the values communicated by traditional devices such as

\section{Informed consumers in quasi-markets}


rulebooks has received attention (Johansson Krafve, 2015). Zuiderent-Jerak and van Egmond (2015) take a more critical stance in their discussion of how values (e.g. fairness and completion) are built into market devices in healthcare as one aspect of dynamic, historical processes.

\subsection{The concepts of interessement and marketing devices in quasi-markets}

Swedish national laws and regulations control the three focal areas in this study. However, the interactions and maneuvering around these laws and regulations, which are common in welfare states, are negotiated and thus delimited (Callon, 1986). Negotiations occur when the government, the providers of public services, and marketing devices used to promote the support technologies for choice are involved in the translation of the public sector to a market player and the citizen to the informed consumer of publicly funded services.

The focus of this study is the increased use of marketing devices (Cochoy, 2007; Mason et al., 2015; McFall, 2014; Ossandón, 2014) that can support citizen choice in the marketplace, offering, for example, education or medical care. Like traditional marketing, marketing devices in a quasi-market guide citizens to technologies supporting choice and the ideal product (Gobby, 2016; Ranerup, 2007; Wilkins, 2012). The marketing devices have different ways of involving humans as users. The novelty is that it happens in a realm in which competition has not been the norm due to the monopolistic position of public sector organizations that are not accustomed to market behavior.

This study is concerned solely with the interessement phase (Callon, 1986) along with the role of the non-human actors represented by market devices (Callon, 1998) and marketing devices (Mason et al., 2015; McFall, 2014; Ossandón, 2014). Callon's first account on the interessement stage was presented as the "redefinition of the identity of wild scallops as domesticated ones" (Cochoy, 2014, p. 113). As Callon (1986, p. 211) explains: "Interessement achieves enrolment if it is successful. To describe enrolment [e.g. of citizens to calculated choice of public services] is thus to describe the group of multilateral negotiations, trials of strength and tricks that accompany the interessements and enable them to succeed." In this study, the interessement contains the details of how the actor network of regulatory forces, technologies and market mechanisms influences public organizations to align with the market logic rather than with the public sector logic. As a consequence, citizens become consumers. Through the influence of marketing devices, they are expected to become calculative consumers in their interaction with, and use of, market devices in citizen choice.

The ANT perspective allows us to study the role of support technologies for choice in a general sense ("market devices"), and the marketing devices and activities used to promote them. The market devices and the marketing devices are, thus, part of a translation process in which negotiations ("interessement") are intended to change public sector behavior and increase citizens' use of technologies for calculative choice. Thus, our focus is not on the more general strategies for enrollment (cf. Allen, 2004), but more explicitly on the role of devices at a micro-level herein that directly interact with citizens. The analysis of three areas of Swedish public services suggests that these interessement activities are embedded in the marketing devices and activities, and the market devices supporting choice, as described in the following sections. The analysis concludes that enrollment is successful: citizens and public organizations align to market behavior.

\section{Material and methods}

Since Sweden has one of the world's broadest and most varied, long-term experiences with welfare markets or quasi-markets for public services with advanced mechanisms of choice, it is considered an "extreme case" (Flyvbjerg, 2006) and a source of knowledge. This empirical study examines three examples of welfare markets: education, healthcare and public pension investing. All are characterized by government having passed laws 
supporting quasi-market arrangements. Eleven agencies in these areas were selected to illustrate the range of public agencies and companies that use marketing devices to promote technologies that support informed choice.

In total, 12 semi-structured interviews (40-90 $\mathrm{min}$ each) with project leaders and managers were conducted from September to November of 2015. These informants have, for several years, worked with, and possess detailed knowledge of, the technological devices supporting choice and the marketing devices and activities used to promote them. However, through a previous round of interviews in 2013 the authors have insights into the general history of technologies supporting choice in all cases except one, albeit not in aspects related to promoting their use. We audio recorded and transcribed all interviews. The purpose of the interviews was to identify how market devices influenced agency. Some interview questions inquired into the technological market devices used to support informed choice. Other questions requested descriptions of current and planned promotional marketing activities such as brochures, letters and advertisements as well as social media presence. Follow-up questions explored the selection of these marketing activities to promote the technological devices to support choice, their outlay and capacity.

Another type of data which guided our work were the appearance of the marketing devices gathered in connection with the interviews as well as in the public space of which one of the authors is part. Being a citizen exposed the author(s) to the ways in which advertising for choice in quasi-markets materializes through, for example, advertisements on billboards, in newspapers and social media. The marketing devices appearing in interviews and as instances of actual marketing devices are described in Tables I-III.

As a final step, based on the principle of symmetry (Callon, 1986), these devices were examined as well as coded with attention to what the marketing devices do (Law and Ruppert, 2013) in the relationship with their human users making up the hybrid calculating agency (Callon, 1998; Callon and Muniesa, 2005). In this manner, in the coding we looked for instances of interessement with the ambition to redefine the identity of citizens as calculating consumers. More specifically, our concern was with the extent to which the marketing devices described in the interviews or in the public spaces acted in a way that indirectly pointed to technological support for choice, via for example printed advertisements. Alternatively, marketing devices in the form of hyper-links might point more directly to technological support for choice, or something in between. An example of the latter was the intention to develop the technology by user participation. The interviewees described this as a means of improving technology's perceived usefulness,
Informed consumers in quasi-markets

1521

\begin{tabular}{|c|c|c|c|}
\hline Owner & $\begin{array}{l}\text { A national public authority: the } \\
\text { Swedish Pensions Agency }\end{array}$ & $\begin{array}{l}\text { A PPP: MyPension.se that } \\
\text { includes The Swedish } \\
\text { Pensions Agency, Banks, } \\
\text { Fund companies }\end{array}$ & $\begin{array}{l}\text { A private company: } \\
\text { CollectiveFundChoice.se }\end{array}$ \\
\hline $\begin{array}{l}\text { Marketing } \\
\text { devices } \\
\text { and } \\
\text { activities }\end{array}$ & $\begin{array}{l}\text { User participation in } \\
\text { development } \\
\text { The Orange Envelope is sent to } \\
\text { citizens yearly with pension } \\
\text { data as well as link and pin } \\
\text { code to MyPension.se.se (the } \\
\text { PPP), social media (blogs, } \\
\text { Facebook), and interviews in } \\
\text { newspapers, and commercial } \\
\text { television } \\
\text { Search optimization }\end{array}$ & $\begin{array}{l}\text { User participation in } \\
\text { development } \\
\text { The Orange Envelope is sent } \\
\text { to all citizens yearly with } \\
\text { pension data as well as link } \\
\text { and pin code to MyPension. } \\
\text { se, banners in online } \\
\text { newspapers, social media } \\
\text { (blogs, Facebook, Instagram, } \\
\text { and Twitter) } \\
\text { Link to choice routine in the } \\
\text { national public support }\end{array}$ & $\begin{array}{l}\text { User participation in } \\
\text { development } \\
\text { Marketing in commercial } \\
\text { television, advertisements in } \\
\text { trains, and social media } \\
\text { (Facebook, Flashback, and } \\
\text { blogs) } \\
\text { Link to choice routine in the } \\
\text { national public support } \\
\text { Search optimization }\end{array}$ \\
\hline
\end{tabular}

Table I. Public pension 
ITP

32,6

1522

Table II.

Healthcare
Owner

An association for all public regional authorities: SALAR and Västra Götaland its IT Department CEHIS

Marketing User participation in devices development and Marketing through the regional activities support and the general branding of the national healthcare portal in line with the branding of the national telephone helpline Search optimization
A public regional authority:

A letter with all primary care centers in the near environment is mailed to citizens

A link from primary care centers to the technological support for choice exists in the national healthcare portal Search optimization
An association: the Swedish Association for Free Enterprise

Focus groups: a medical advisory group participated in the development Social media (e.g. Twitter, videos), press/news, and participation in competitions and fairs

thereby increasing its use. The intention was to discern constellations of marketing devices connecting technologies to humans in addition to their directness and strength in the interessement stage. Our aim is not to pursue a longitudinal analysis of the interessement and enrollment stages (cf. Nguyen et al., 2017), but to capture constellations and capacities during a limited period of time. A last step consisted of sorting the constellations to construct a typology.

\section{Analysis}

\subsection{The actor-network of the Swedish quasi-market}

In our empirical account and analysis, we will make use of the ANT feature of incorporating macro- and micro-level actors (cf. Fornazin and Joia, 2016; Law and Hassard, 1999; McLean and Hassard, 2004). However, we will look more closely at some of them (Cresswell et al., 2010). For the sake of simplicity, in Figure 1, we show the main constellations of actors at a certain point in time, but not the details of the translation processes as a whole (Silvis and Alexander, 2014). From the 1990s, inspired by the discourse of more government for less money (Osborne and Gaebler, 1992), national actors in Sweden introduced legislation about choice reform.

Primary and secondary education is the public service area in Sweden with the longest history of citizen choice. In the 1990s, education choice became a hallmark of public school education - in 1992 for primary and lower secondary education, and in 1994 for upper secondary education. A citizen can choose a primary or secondary school as well as upper secondary education.

National authorities regulate healthcare in collaboration with 21 county councils that manage and operate healthcare. In 2010, the county councils were required to introduce plans for patient choice of primary healthcare providers (although not physician choice). The default arrangement is a community model based on primary care centers with responsibility for a district and with an additional choice option. In 2000 premium pension funds were introduced as an obligatory part of general pension reform (SOU, 2005). A portion of each citizen's employment earnings is set aside annually under the Swedish premium pension plan and placed in an individual portfolio. Annually, citizens can choose from among 800 premium pension funds administered by private agencies, banks, and a public company. This means that citizens can choose their quasi-markets services in education, healthcare and public pension.

More importantly, actors in the form of organizations featuring as hosts have introduced and designed technologies supporting citizens' choice. These hosts and their technologies supporting citizen choice are situated at the national, regional or local level. Furthermore, the hosts can be public, private or PPPs organizations and companies. The hosts use marketing devices to promote the use of the technology that supports citizens' choice. In the following section, to explore the ways in which citizens are aligned to market behavior, we will examine the hosts, 


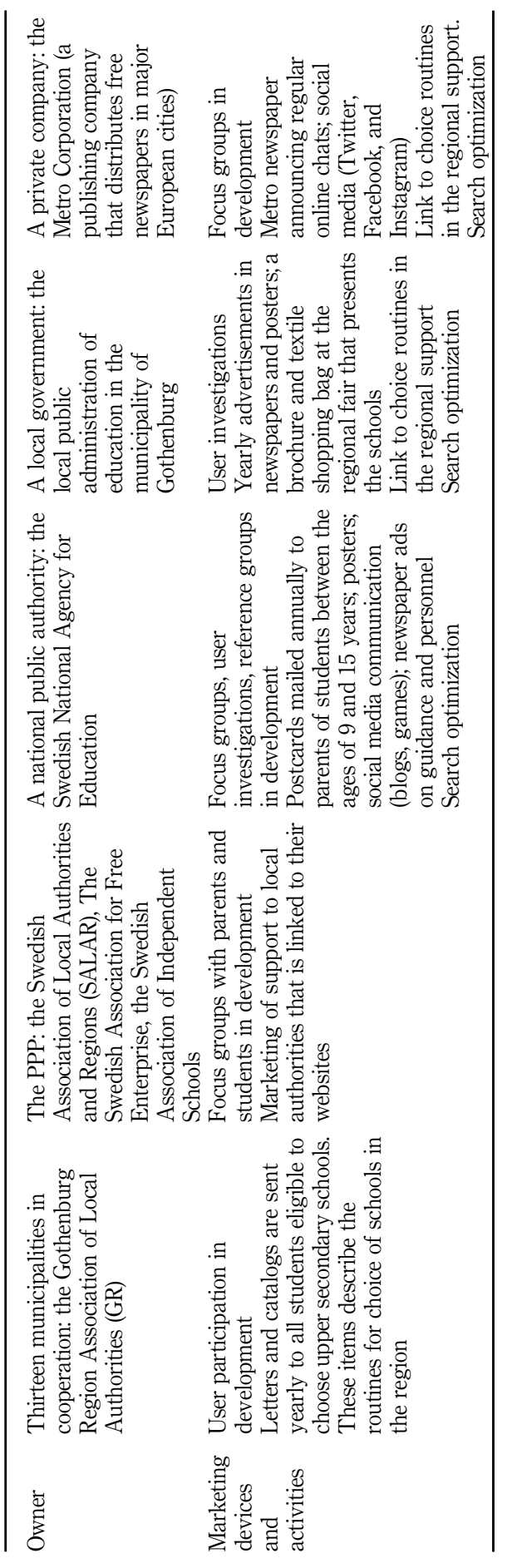

Informed consumers in quasi-markets

1523

Table III.

Education 
Actors and devices
Figure 1.

The actor-network of the Swedish quasi-market
Hosts (national, regional, local, public, private, semi-private) providing technologies supporting choice

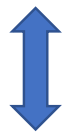

Marketing devices

(social media, user participation, search optimization, billboards)

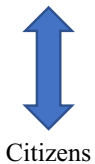

their technologies, and the marketing devices in education, healthcare and public pension. This enables an analysis within and between areas, of the interessement in the market devices and of the marketing devices that negotiate and translate the program of choice.

\subsection{Education}

In education, the translation process includes many types of hosts that provide technologies to support informed choice. There is considerable competition among them for students and parents. The five examples (municipal and national public authorities, the PPPs and a private company) represent the range of actors providing technological support for choice at the local, regional and national levels (Table III, row 1).

All five instances of technological support offer information about the rights of choice. However, there are variations in their ability to support qualified comparisons of education options. Only three of the five enable the user to make the actual education choice using links to choose devices: the regional public authority, the local government and the private company.

All hosts, except the PPP, have regular marketing campaigns for the annual choice of upper secondary education for students between the ages of 16 and 18 years and for the technological support for choice. Choosing upper secondary education in this manner is thus obligatory but choosing primary and secondary education is not, because students are placed in the school run by the municipality that is closest to their place of residence. A local government respondent and a national public authority respondent describe their marketing campaigns:

We promote choice for upper secondary schools largely through the Gothenburg Region Association of Local Authorities and by our web-based support [...] We do this with the special annual education fair for upper secondary education dedicated to the specific group of 15-year olds who are ready to make a choice. We also issue a catalogue that describes our municipal schools. (Project leader, The Municipal Administration for Education, Gothenburg, October 4, 2015)

Regarding the technological support for choice we plan to send postcards to students aged 11, or rather to their parents, and to students aged 15. This is what we can afford in our budget. [...] When it comes to [another technological support for choice of upper secondary education] we have 
focused on young people who blog. We have created a digital game and a magazine. (Project leader, The Swedish National Agency for Education, September 24, 2015)

The local government explains its marketing devices and activities:

The billboards in town [...] are well-functioning and visible. [...] The idea for posting advertisements on the trams came about when we realized that was where the non-municipal schools attract visitors. (Project leader, The Municipal Administration for Education, Gothenburg, April 10, 2015)

The Gothenburg Region Association of Local Authorities has direct links to its technological support for making the choice in education as well as events such as its annual education fair. They also distribute letters and catalogs to households. In other words, there is a repertoire of ways of indirect marketing. Some marketing devices include social media in the form of blogs with a more explicit capacity to stimulate interaction between potential users and the actor providing the technological support for choice. In contrast, because of its limited marketing budget, the PPP discusses education choice by reference to the Swedish National Agency for Education:

When we launched this, the Swedish National Agency for Education received its assignment [to improve their website supporting choice]. But we think that we could co-ordinate our activities because the government has more economic resources. [...] But once we had our website, they qdid their job. One could say that this was a kind of lobbying. (Project leader of the PPP, September 22, 2015)

The private company also uses marketing devices and activities to promote technological support for choice:

We had videos with interviews [about choice in education]. We uploaded them to celebrity Twitter accounts, Facebook and Instagram, and the like. [...] Because of these celebrities, the videos reached many people. This is kind of what we do today. However, of course we try to work with search optimization so people will find us when they search for education. (Project leader, The Metro Corporation, September 19, 2015)

Search optimization is achieved by tagging organic search results and by paid search optimization. Several hosts acknowledge the value of search optimization for drawing attention to their services. Search optimization is an invisible but powerful marketing device.

Advertisements including social media are used to promote annual choice of upper secondary education and the technological support for choice. The Metro Corporation has a link on its website to the regional technological support for actual choice in education. In this manner, providing direct links to a technological support for making the actual choice is part of a repertoire of marketing devices of both public and private actors.

\subsection{Healthcare}

Three hosts and their marketing devices related to technological support for choice were examined in primary healthcare (Table II). Regional public associations own and operate two instances of technological support. A private organization that promotes free enterprise owns and operates the third. The two public associations provide information about the right of choice. The private association does not. All three associations support advanced search functions for primary care centers and facilitate comparisons based on geographic location, ownership and patient evaluations. The technological support for choice at the private association also allows the ranking of options. The two public associations allow users to choose between public and private options.

Data on the marketing devices for technological support for choice in healthcare reveal that there are fewer attempts to increase citizen involvement here than in education.

\section{Informed consumers in quasi-markets}

1525 
Despite some evidence of user participation in the development of technological support for choice in the instances of technological support, the marketing activities mainly relate to the citizens' use of the technologies. The two public instances link to the same national website:

Generally speaking, we haven't engaged in any direct marketing activities. But our channels in our regional webpages are directed to [...] the national portal 1,177 The Healthcare Guide. Then [the technological support for choice] is reached by a link from our channels. (Civil servant, The Public Regional Authority Västra Götaland, November 9, 2015)

The regional authorities said that their main channel, their common window to citizens, should be the national portal 1,177 The Healthcare Guide. [...] And they don't want to build up these things locally $[\ldots .$.$] but rather at a national level in a clearer manner. (Project leader, SALAR/CEHIS,$ October 6, 2015)

The public regional actor Västra Götaland does benefit from the technological support for choice provided at the national level. Technological support for choice is thus a choice among public sector alternatives rather than between the public and private sectors. The private actor that provides technological support for choice, financed by the Swedish National Association for Free Enterprise, operates on a commercial basis. This instance of technological support offered several marketing activities until closing in February 2016:

We had financial support from the Swedish National Association for Free Enterprise for three years or three and a half years. [...] We had some smaller funding from providing data analysis [from among others] The Swedish Competition Authority and large private companies in healthcare. [...] It is a vicious circle if you are incapable of staying active in the development of the technology. (Manager, private company supported by The Swedish Association for Free Enterprise, September 22, 2015)

In its years of active marketing, the private company participated in IT competitions in healthcare and in Twitter exchanges. Citizens could tweet about the technological support for choice in healthcare with users of and representatives from other healthcare organizations. As in education, social media is used as a marketing device with a capacity to create interaction between potential users and the host by marketing its support for choice.

\subsection{Public pension investing}

Three hosts providing technological support for choice were examined in public pension investing: a national public authority, a PPP and a private company (Table I). The first two provide technological support that includes information about the right of choice. Only the public authority presents a complete listing of fund comparisons by type, risk level and fees. This option also makes investment return projections from a short- and sometimes from a long-term perspective. It also facilitates comparisons among fund portfolios and projected portfolio changes.

The private company provides limited support for making comparisons between present portfolio investments and other investment options. These comparisons are based on ongoing analyses of the best choices made by other users of this technological support for choice. This instance provides direct links to the technological support for choice provided by the national public authority. Thus, users can access its functionality for choosing funds "from a distance."

The technological support for choice by the PPP displays the assets in an individual's pension portfolio by source. It also includes functions to predict pension distributions depending on retirement age and projected earnings until retirement.

As for marketing and increasing use, the public authority encourages pension investors to use its technological support through the annual letter ("The Orange Envelope") (Plate 1). 

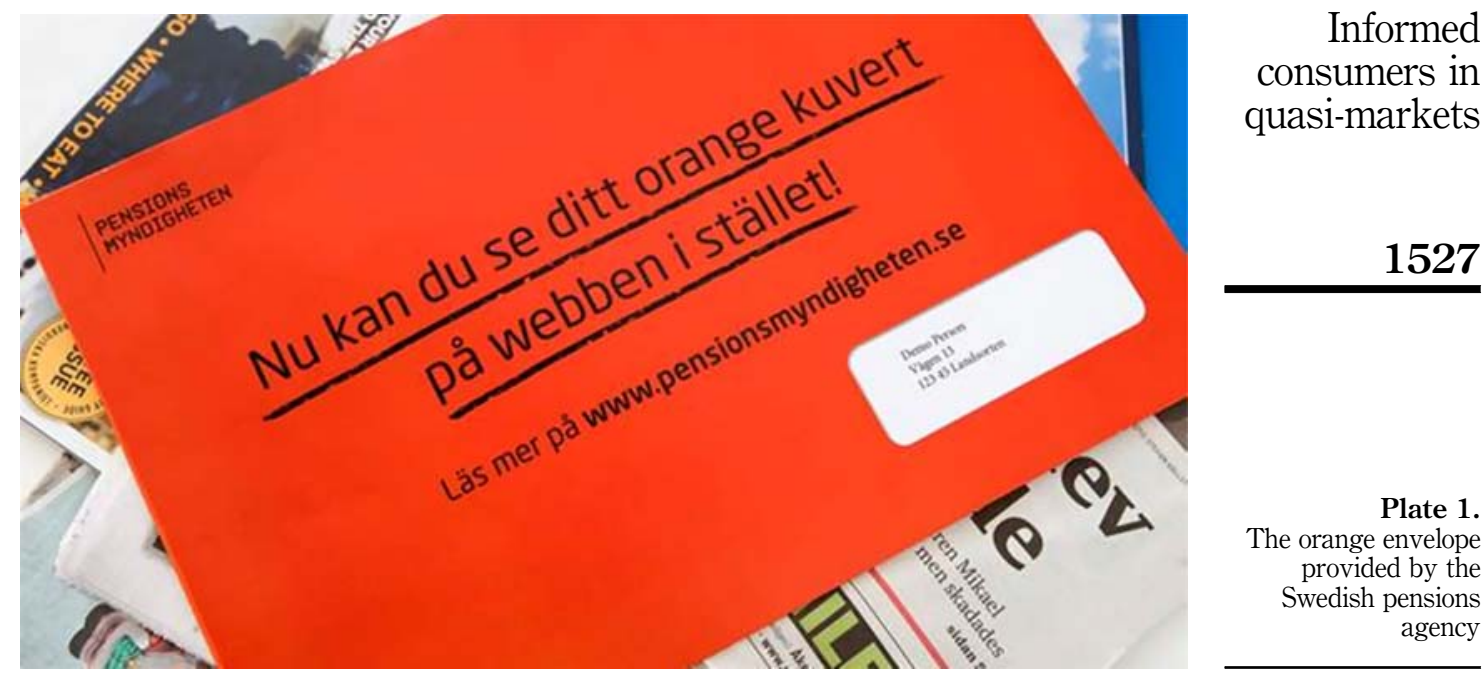

1527

The same message is found in their web-based support for choice: "The Swedish Pension Agency recommends that you repeat this procedure once a year, because your attitude towards risk and your portfolio value can change" (Ranerup, 2007, p. 158). The PPP recommends usage on a "regular basis." The private company sends an SMS message as a reminder to pension investors and recommends that they review their portfolio once a month (Kollektivafondval.se, accessed September 10, 2015).

All three instances have some user participation in the development of the technological support for choice. However, the history of the national public authority instance and the PPP instance is much longer (approximately 15 years); the private company was not founded until the autumn of 2015. This means user participation in the first two instances take user input into account for the design and redesign of technology, but the private company has not yet established itself in the market. The user participation is intended to provide support that fits all users, experienced or not, thereby increasing use.

All instances use social media platforms such as blogs, Facebook, Twitter and Instagram. They also use more traditional mass media marketing outlets, such as commercial television and online newspapers:

We have a film we provide through Aftonbladet [an online newspaper] and other websites, as well as banners. [...] Our blog is the most successful [of our social media marketing], but we also have 2000 followers on Twitter, but maybe only 100-150 followers on Instagram and Facebook. (Project leader, PPP, MyPension.se, October 22, 2015)

As mentioned, the national public authority sends the "Orange Envelope," annually to pension investors (Plate 1). This letter details pension contributions, pension distributions and pension return projections. The national public authority also has a website where users can access this information using a PIN. The text on the outside of the Orange Envelope states [translated] [...] "Now you can see your Orange Envelope on the web! [followed by the URL]." A respondent describes:

[Marketing] is mostly through the Orange Envelope [...] and obviously like all functioning organizations today, we have a website with more general information that we also use to provide more specific information. (Project leader, The Swedish Pensions Agency, October 25, 2015) 
The Orange Envelope, a central marketing device for pensions, appears traditional. However, it contains a URL establishing an indirect link to the technological device supporting choice. One respondent describes a linkage between the national public authority and the PPP:

Thus, we have an individualized support that is generated through a person's own data about savings as the basis for a pension forecast. [...] It is the same service. One can go to it through the [PPP website] MyPension.se, and through The Swedish Pensions Agency. (Project leader, The Swedish Pensions Agency, October 25, 2015)

The private company uses "collective intelligence," which is Big Data analysis of previous pension investors' activities to make fund recommendations. In this way, previous pension investors' choices and returns can be used as the basis for advice on fund choices. This is a free service for pension investors. (Users must log on to the actual public pension portfolio in the public national instance.) Many marketing activities are designed to enroll citizens as users and include traditional material advertisements in public transport in addition to social media (e.g. Facebook, YouTube, Flashback):

We, including myself, are professional marketing people. We use national commercial television for commercials [...]. We use the channels that have the biggest access to our potential users, at the lowest cost. [...]. Right now commercial television or maybe Facebook is the cheapest means of marketing, but we often combine the two in order to achieve satisfactory outreach to customers. We have gone from zero to thousands of users in our first five weeks [...]. Our growth rate greatly exceeds our expectations. (Project leader, CollectiveFundChoice.se, September 29, 2015)

\section{Result: an overview of marketing devices in quasi-markets}

The empirical materials reveal many marketing devices and activities. The technological support for choice is marketed through material objects such as product catalogs, postcards, the Orange Envelope and shopping bags in addition to presence marketing through social media and television and newspaper ads. Key representatives from the hosts also give television and newspaper interviews.

In addition to using these marketing devices, citizens themselves are directly involved in the translation. Besides the use of Web 2.0 technologies (e.g. Facebook, Twitter and Instagram), citizens participate in developing the systems by reporting on their user experiences and evaluating the usefulness of the technologies.

This analysis of the three areas of marketing devices and activities (see Tables I-III) confirms descriptions by Teerling and Pieterson (2011) and Kernaghan (2013) of marketing and channel management activities undertaken through user participation. More importantly, this research expands on their findings by creating a five-item typology (Leonardi and Barley, 2008). The typology illustrates the ways in which citizens become consumers.

A first type refers to the devices and activities that draw citizens' attention to the opportunity for making choices. These material devices (Law and Ruppert, 2013) highlight the technological support for choice in a general sense. The devices resemble traditional marketing whose objective is to catch the attention of a potential consumer. The marketing devices and activities include advertisements, catalogs and mailings which establish indirect connections between services, support technologies for choice and users. The advertisements are embedded in digital and physical artefacts such as shopping bags and postcards. These connections invite more direct interaction; if used, they can strengthen citizens' ability to make informed or calculated market choices (Callon, 1998; Callon and Muniesa, 2005).

A second type refers to the role in which citizens' attention is drawn to the issue of choice and to the invitation to human interaction with agency representatives supplying the technology to support choice (Figure 1). Their capacity to act to influence citizens is most likely stronger (Callon, 1986) than the first type. These marketing devices and activities include blogs, Twitter, 
Facebook and Instagram that support two-way communication, build a platform for information sharing (Andersen et al., 2012), and support transparency and collaboration (Bertot et al., 2012). However, in contrast to other research (Rodriguez and Manuel, 2017) both public and private agencies are active. This type of marketing devices includes education fairs (Van Zanten and Legavre, 2014) to which citizens are invited. The interviewees commented on the importance of education fairs, since they attract visitors and invite face-to-face and online interaction.

A third type refers to user participation in the design of technological support for choice. The aim of such participation is to satisfy users' requirements and needs, thereby hopefully increasing use (Teerling and Pieterson, 2011). An example is the user participation in the design and redesign of pension investment data presentation by the public national agency and the PPP. The involvement of users in co-production (Scott and Orlikowski, 2012) strengthens the bond between an agency, its technology-supporting choice and the citizen. The pension investment data are an example of the use of calculative devices (Azimont and Araujo, 2010) to influence the citizen's choice. However, the details about data and functionality must be tailored to each user's age, risk preferences and level of interest.

A fourth type of search optimization facilitates finding the technological support for choice when citizens look for information on public services. In the interessement phase and its activities, this marketing device brings the technology-supporting choice to the user. This search optimization and web algorithms of (Google) search engines are indispensable to the needs of the "calculating public" (Birkbak and Carlsen, 2015). However, this marketing device is so subtle that users might not even be aware of the possible manipulation embedded in search optimization (Introna and Nissenbaum, 2000). The search optimization is characterized by a continuous development of algorithmic interfaces (Eslami et al., 2015) influencing listings, rankings and suggestions for the user leading to a "hypernudge" (Yeung, 2017) where algorithmic decision-guidance techniques are embedded in the design of the market devices.

A fifth type refers to the activity in the interessement phase of connecting humans to the technological support for choice directly through links to the technological devices with their functionality for choice. The technologies that support choice in many of the studied instances provide links to their own technological device or another agency's device one can use to make an actual choice online. An example from this study is the Orange Envelope that presents pension investment data. Written on the outer envelope is, "Now you can see your Orange Envelope online," followed by the URL of the site (Plate 1).

These five types of marketing devices and activities were identified in all three areas of public service studied here. As Law and Ruppert (2013) comment in their description of devices as "patterned teleological arrangements," devices "do things." Thus, what marketing devices and activities do depend on their intended purposes and outlay. Thereby, in various ways and in various degrees these devices and activities strengthen their own ability to make citizens into informed consumers.

However, our analysis shows that some hosts in this study not only use marketing devices but also introduce what can be termed "choice routines" as to connect citizenconsumers in quasi-markets. The choice routines were detected through a holistic analysis of the empirical account of the interviewees. They can therefore be seen as both resembling and showing the limits of a marketing device.

As an example of the system of repeat routines for choice, the education providers regularly use devices and activities to encourage enrollment of citizens as active choosers. Although active choice is mandatory for upper secondary education, this is not the case with primary and lower secondary education. Without active choice at this level, students between the ages of 7 and 15 will study at the municipal schools closest to their homes.

Another even stronger instance of interessement is the repeat routines for choice in the interaction of citizens and the pension agencies and companies that offer choice of funds.

\section{Informed consumers in quasi-markets}

1529 
ITP

32,6

1530

The Orange Envelope sent annually to pension investors invites their analysis, countercheck and evaluation by means of the technological support for choice. The Orange Envelope also contains direct links to the technological support provided by the PPP. The private company promotes and recommends monthly use. In this manner, there is an intention to stimulate regular choice activities or repeat routines for choice.

This finding might be less applicable in healthcare in which active choice is required only when citizens change residence or want to change a primary care provider. People who do not make a choice have a "default" public alternative.

\section{Conclusion}

$R Q 1$. How are technological marketing devices used to shape citizen-consumers in quasi-markets?

Based on a Swedish case study, this paper uses qualitative data from 11 occurrences of technologies to support citizens' choice education, healthcare and public pension in an analysis of the means taken to increase their use. The conclusion is that public agencies, PPPs and private companies taking the same steps to turn citizens into informed consumers. They use similar marketing devices and activities, especially technology, that are marketed in a variety of ways, as illustrated by the five-item typology. The typology highlights the variation in categories of marketing devices and activities used to enroll citizens in customer behaviors.

Actors that provide technological support for choice in education, healthcare and public pension investing have aligned with the marketing devices and activities used in the private sector. There were few noteworthy differences in their marketing efforts. All actors use commercial marketing devices and activities that feature social media, traditional media and user participation in the design and redesign of their technological services. A further result is therefore that the interessement process (Callon, 1986) of enrolling citizens is multifaceted, but that public, private and public-private organizations were operating in similar ways.

However, there are several differences among the areas of education, healthcare and pension regardless of the actor that provides the technological support for choice and the marketing to increase use. One exception is that there are more levels and actors in education (national, regional and local) than in the other two areas. Another exception is the attempt to create choice routines in education and public pension, but not in healthcare. In fact, the national healthcare portal, 1,177 The Healthcare Guide, is motivated by an alternative logic in which citizens are encouraged to manage some of their own health-related problems through self-management. Perhaps there is a lack of marketing of repeat routines for choice in healthcare because personal, continuous care is more relevant and necessary for patients with chronic illnesses and conditions (Hjortdahl and Laerum, 1992); these patients are signed into health management plans via other channels.

In his book comparing public and private organizations, Bozeman (2004) boldly claims that "all organizations are public." He argues that regulations and market factors control all organizations. This research, at least on a practical level, supports this claim. However, we add that "all organizations, public and private, use the same marketing devices." The public agencies, the PPPs, and private companies examined here follow the same commercial marketing logic and compete for the same customers.

Our findings make three contributions. First, the proposed typology of marketing devices and activities in the public service arena adds to the research in e-government, the research on channel management (Kernaghan, 2013; Teerling and Pieterson, 2011) and 
citizens' adoption of technology. It offers a joint or holistic view of all measures taken to increase citizens' technology use, emphasizing the role of these measures as intermediaries between citizens and technologies. It thus offers an understanding to the applied theoretical perspective of ANT related to market devices and marketing devices (Callon, 1998; Callon and Muniesa, 2005), that expands the scope of details of the interessement activities to accomplish enrollment before actual choice of services provided by the various channels.

In contrast to other research on citizens' adoption of technologies (Carter et al., 2016; Gupta et al., 2016), the applied theoretical perspective describes these multilateral negotiations, of which marketing devices are an important part, with a nuanced perspective on the nature of support technologies and the citizens who are supposed to use them. The five-item typology shows how marketing devices and activities affect the adoption of technologies by features that advertise their strengths and their capacity to promote enrollment. The application of theory and the typology make use of a capacity in ANT to be explicit about not only human but also non-human actors (Callon, 1986; Mwenya and Brown, 2017). In other words, in this study and in our typology, the agency of humans (citizens), and of non-human marketing devices is described and considered.

Second, our empirical case is a quasi-market arrangement in Sweden. The introduction of support technologies for choice in education, healthcare and public pension investing is thus part of a translation process in which they, with marketing devices intended to increase their use, influence the presentation and delivery of public services in the welfare markets (Johansson Krafve, 2015; Zuiderent-Jerak and van Egmond, 2015). However, the actors that provided the choice-supporting technologies and the marketing devices were public, semiprivate and private. Few differences in their use of marketing devices were found. Therefore, a result of this study is the details of how citizen-consumers are shaped by technologies and marketing devices thereby becoming enrolled to market behavior. A contribution is also the details of how public organizations are enrolled to market behavior.

Third, the setting of this study is three public service areas in Sweden's quasi-market (Johansson Krafve, 2015; Zuiderent-Jerak and van Egmond, 2015). In this setting, using ANT takes the citizen-consumer's point of view on marketing devices and activities (McFall, 2014; Mason et al., 2015), not the provider's or the professional's (Greenhalgh et al., 2014). We can therefore concentrate on the marketing devices and activities as understood and used by citizen-consumers. In this way, this study compensates for citizens' information deficit (Fotaki et al., 2008; Nordgren, 2010), which is being debated in the regulation of quasi-markets (Johansson Krafve, 2015).

\section{Limitations and future studies}

Our research is limited to quasi-markets and marketing devices related to technological and other support for choice in three areas in the Swedish welfare state: education, healthcare and public pension investing. However, because Sweden is an "extreme case" (Flyvbjerg, 2006), the result has a high value to other countries in which such arrangements are less widespread. An additional value is the typology of marketing devices and their qualities of relevance to broader attempts to increase citizens' technology use.

Of course, user studies are an important area for further research. For one thing, there might be significant differences between users and areas of quasi-market services in terms of their access to, and knowledge about, technology. Researchers could study more closely the messages that technology providers send or produce with their selection and use of marketing devices. This study addresses the general forms of these marketing devices. A detailed analysis of these logics and their content might reveal important distinctions among the hosts or providers. In a critical analysis of the socio-technical perspective on markets, Gane (2012) claims that the commentary on devices or "small things," while of 
interest, often lacks a critical discussion of "big issues" such as neoliberalism. We do not deny the importance of such critical discussions, but we also suggest that the study of "small things" (i.e. marketing devices and activities) in quasi-markets, especially when framed as case studies or qualitative studies of designated areas, is fundamental to understanding how technologies to support choice are marketed in an era that promotes the logic of neoliberalism in the public sector. It is beyond the scope of this study to discuss whether or not it is appropriate for public agencies to spend resources on marketing efforts. Public sector organizations do invest in those activities even though they pull the public sector in a different direction. Our analysis therefore has a critical aim (Doolin and Lowe, 2002).

\section{References}

Allen, J.P. (2004), "Redefining the network: enrollment strategies in the PDA industry", Information Technology \& People, Vol. 17 No. 2, pp. 171-185.

Andersen, K.N., Medaglia, R. and Henriksen, H.Z. (2012), "Social media in public health care: impact domain propositions", Government Information Quarterly, Vol. 29 No. 4, pp. 462-469.

Azimont, F. and Araujo, L. (2010), "The making of a petrol station and 'on the move consumer': classification devices and the shaping of markets", Industrial Marketing Management, Vol. 39 No. 6, pp. 1010-1018.

Bertot, C.J., Jaeger, P.T. and Grimes, J.M. (2012), "Promoting transparency and accountability through ICTs, social media, and collaborative e-government", Transforming Government: People, Process and Policy, Vol. 6 No. 1, pp. 78-91.

Birkbak, A. and Carlsen, H.J. (2015), "The public and its algorithms", in Amoore, L. and Piotukh, V. (Eds), Algorithmic Life. Calculative Devices in the Age of Big Data, Routledge, London and New York, NY.

Bozeman, B. (2004), All Organizations are Public. Comparing Public and Private Organizations, Beard Books, Washington DC.

Callon, M. (1986), "Some elements of a sociology of translation: domestication of the scallops and the fishermen of St Brieuc Bay", in Law, J. (Ed.), Power, Action and Belief: A New Sociology of Knowledge?, Routledge \& Kegan Paul, London, pp. 196-233.

Callon, M. (1998), "The embeddedness of economic markets in economics”, in Callon, M. (Ed.), The Laws of the Market, Blackwell Publishers, Oxford, pp. 1-57.

Callon, M. (2016), "Revisiting marketization: from interface-markets to market-agencements", Consumption, Markets and Culture, Vol. 19 No. 1, pp. 17-37.

Callon, M. and Muniesa, F. (2005), "Economic markets as calculative collective devices", Organization Studies, Vol. 26 No. 8, pp. 1229-1250.

Carey, G., Dickinson, H., Malbon, E. and Reeders, D. (2018), “The vexed question of market stewardship in the public sector: examining equity and the social contract through the Australian national disability insurance scheme”, Social Policy \& Administration, Vol. 52 No. 19, pp. 387-407.

Carter, L., Weerakkody, V., Phillips, B. and Dwivedi, Y.K. (2016), "Citizen adoption of E-Government services: exploring citizen perceptions of online services in the US and UK", Information Systems Management, Vol. 33 No. 2, pp. 124-140, doi: 10.1080/10580530.2016.1155948.

Clarke, J., Newman, J., Smith, N., Vidler, E. and Westmarland, L. (2007), Creating Citizen-Consumers. Changing Publics and Changing Public Services, Sage, London.

Cochoy, F. (2007), “A brief theory of the 'captation' of publics: understanding the market with little red riding hood”, Theory, Culture \& Society, Vol. 24 Nos 7-8, pp. 203-223.

Cochoy, F. (2014), “A theory of 'agencing': on Michel Callon's contribution to organizational knowledge and practice", in Adler, P.S., du Gay, P., Morgan, G. and Reed, M. (Eds), The Oxford Handbook of Sociology, Social Theory, and Organizational Studies: Contemporary Currents, Oxford University Press, Oxford, pp. 106-124. 
Cordella, A. and Hesse, J. (2015), "E-government in the making: an actor network perspective", Transforming Government: People, Process, Policy, Vol. 9 No. 1, pp. 104-125.

Cresswell, K.M., Worth, A. and Sheikh, A. (2010), "Actor-network theory and its role in understanding the implementation of information technology developments in healthcare", BMC Medical Informatics and Decision Making, Vol. 10, p. 67, available at: https://doi.org/10.1186/1472-6947-10-67

Doolin, B. and Lowe, A. (2002), "To reveal is to critique: actor-network theory and critical information systems research", Journal of Information Technology, Vol. 17 No. 1, pp. 69-78.

Eslami, M., Rickman, A., Vaccaro, K., Aleyasen, A., Vuong, A., Karahalios, K. and Sandvig, C. (2015), "I always assumed that I wasn't really that close to [her]: reasoning about invisible algorithms in news feeds", Proceedings of the 33rd Annual ACM Conference on Human Factors in Computing Systems, April, pp. 153-162.

Flyvbjerg, B. (2006), "Five misunderstandings of case-study research", Qualitative Inquiry, Vol. 12 No. 2, pp. 219-245.

Fornazin, M. and Joia, L.A. (2016), "Techno-government networks: actor-network theory in electronic government research”, in Scholl, H.J., Glassey, O., Janssen, M., Klievink, B., Lindgren, I., Parycek, P., Tambouris, E., Wimmer, M.A., Janowski, T. and Sá Soares, D. (Eds), Electronic Government. EGOV 2016, Lecture Notes in Computer Science, Vol. 9820, Springer, Cham, pp. 188-199.

Fotaki, M., Roland, M., Boyd, A., McDonald, R., Scheaff, R. and Smith, L. (2008), "What benefits will choice bring to patients? Literature review and assessment of implications", Journal of Health Services Research Policy, Vol. 13 No. 3, pp. 178-184.

Gane, N. (2012), "Material markets: how economic agents are constructed", Theory, Culture \& Society, Vol. 29 No. 2, pp. 150-153.

Gilbert, D., Balestrini, P. and Littleboy, D. (2004), "Barriers and benefits in the adoption of e-government”, International Journal of Public Sector Management, Vol. 17 No. 4, pp. 286-301.

Gobby, B. (2016), "Obliged to calculate: my school, markets, and equipping parents for calculativeness", Journal of Education Policy, Vol. 31 No. 4, pp. 421-431.

Graham, T.J. (2016), "Technologies of choice: the shaping of choice on the World Wide Web", PhD Dissertation, The University of Queensland, available at: http://dx.doi.org/10.14264/uql.2016.865 (accessed August 25, 2017).

Greenhalgh, T., Stones, R. and Swinglehurst, D. (2014), "Choose and book: a sociological analysis of 'resistance' to an expert system”, Social Science \& Medicine, Vol. 104, pp. 210-219.

Gupta, K.P., Singh, S. and Bhaskar, P. (2016), "Citizen adoption of e-government: a literature review and conceptual framework", Electronic Government, An International Journal, Vol. 12 No. 2, pp. 160-185.

Hanseth, O., Aanestad, M. and Berg, M. (2004), "Actor-network theory and information systems. What's so special?”, Information Technology \& People, Vol. 17 No. 2, pp. 116-123.

Heeks, R. and Stanforth, C. (2007), "Understanding e-government project trajectories from an actor network perspective", European Journal of Information Systems, Vol. 16 No. 2, pp. 165-177.

Hjortdahl, P. and Laerum, E. (1992), "Continuity of care in general practice: effect on patient satisfaction”, British Medical Journal, Vol. 304 No. 1287, pp. 1287-1290.

Introna, L.D. and Nissenbaum, H. (2000), "Shaping the web: why the politics of search engines matters", The Information Society, Vol. 16 No. 3, pp. 169-185.

James, J. (2014), "Mobile phone use in Africa: implications for inequality and the digital divide", Social Science Computer Review, Vol. 32 No. 1, pp. 113-116.

Johansson Krafve, L. (2015), "Valuation in welfare markets: the rule books, whiteboards and swivel chairs of care choice reform", $\mathrm{PhD}$ Dissertation, Linköping University, Linköping.

Karpik, L. (2010), Valuing the Unique: The Economics of Singularities, Princeton University Press, Princeton, $\mathrm{NJ}$ and Oxford.

Kernaghan, K. (2013), "Changing channels: managing channel integration and migration in public organizations", Canadian Public Administration, Vol. 56 No. 1, pp. 121-141. 
ITP

32,6

1534

Latour, B. (1987), Science in Action. How to Follow Scientists and Engineers Through Society, Harvard University Press, Cambridge, MA.

Law, J. and Hassard, J. (1999), Actor Network Theory and After, Blackwell, Oxford.

Law, J. and Ruppert, J. (2013), “The social life of methods: devices”, Journal of Cultural Economy, Vol. 6 No. 3, pp. 229-240.

Le Grand, J. (2009), The Other Invisible Hand. Delivering Public Services Through Choice and Competition, Princeton University Press, Princeton, NJ.

Leonardi, P.M. and Barley, S.R. (2008), "Materiality and change: challenges to building better theory about technology and organizing", Information and Organization, Vol. 18 No. 3, pp. 159-176.

McFall, L. (2014), "Chapter 3: what have market devices got to do with public policy? For regulation, market devices, and public policy collection", in Halpern, C., Lascoumes, P. and Le Galés, P. (Eds), L'instrumentation de l'action publique, Presses de Sciences Po, Paris, pp. 119-142.

McLean, C. and Hassard, J. (2004), "Symmetrical absence/symmetrical absurdity: critical notes on the production of actor network theory", Journal of Management Studies, Vol. 41 No. 3, pp. 493-519.

MacKenzie, D. (2009), Material Markets: How Economic Agents are Constructed, Oxford University Press, Oxford.

Mason, K., Kjellberg, H. and Hagberg, J. (2015), "Exploring the performativity of marketing: theories, practices and devices", Journal of Marketing Management, Vol. 31 Nos 1-2, pp. 1-15.

Mensah, I.K. (2018), "Citizens' readiness to adopt and use e-government services in the city of Harbin, China", International Journal of Public Administration, Vol. 41 No. 4, pp. 297-307.

Mwenya, J.K. and Brown, I. (2017), "Actor-network theory in IS research: critique on application of the principle of generalized symmetry", Proceedings of SAICSIT, Thaba Nchu, 26-28 September.

Nguyen, L., Wickramasinghe, N., Redley, B., Haddad, P., Muhammad, I. and Botti, M. (2017), "Exploring nurses' reactions to electronic nursing documentation at the point in care", Information Technology \& People, Vol. 30 No. 4, pp. 809-831.

Nordgren, L. (2010), "Mostly empty words - what the discourse of 'choice' in health care does", Journal of Health Organization and Management, Vol. 24 No. 2, pp. 109-126.

Osborne, D. and Gaebler, T. (1992), Reinventing Government: How the Entrepreneurial Spirit is Transforming the Public Sector, Addison-Wesley, Reading, MA.

Ossandón, J. (2014), "Sowing consumers in the garden of mass retailing in Chile", Consumption Markets \& Culture, Vol. 17 No. 5, pp. 429-447.

Ranerup, A. (2007), "Electronic government as a combination of human and technological agency: testing the principle of symmetry", Information Polity, Vol. 12 No. 13, pp. 153-167.

Ranerup, A., Henriksen, H.Z. and Hedman, J. (2016), "An analysis of business models in public service platforms", Government Information Quarterly, Vol. 33 No. 1, pp. 6-14.

Rodriguez, B. and Manuel, P. (2017), "Government models for the delivery of public services through the web 2.0 technologies: a political view in large Spanish municipalities", Social Science Computer Review, Vol. 35 No. 2, pp. 203-225.

Roscoe, P. (2013), "Economic embeddedness and materiality in a financial market setting", The Sociological Review, Vol. 61 No. 1, pp. 41-68.

Roscoe, P. and Chillas, S. (2014), "The state of affairs: critical performativity and the online dating industry", Organization, Vol. 21 No. 6, pp. 797-820.

Scott, S.V. and Orlikowski, W.J. (2012), "Reconfiguring relations of accountability: materialization of social media in the travel sector", Accounting, Organizations and Society, Vol. 37 No. 1, pp. 26-40.

Silvis, E. and Alexander, P.M. (2014), "A study using a graphical syntax for actor-network theory", Information Technology \& People, Vol. 27 No. 2, pp. 110-128. 
Söderström, F. (2016), "Introducing public sector eIDs - the power of actors' translations and institutional barriers", $\mathrm{PhD}$ dissertation, Linköping University, Linköping.

SOU (2005), "Difficult waters? Premium pension savings on course (Svårnavigerat? Premiumpensionssparande på rätt kurs?)”, SOU 2005:8, Swedish Government Official Reports, Fritzes, Stockholm.

Teerling, M.L. and Pieterson, W. (2011), "How to improve e-government use: an empirical examination of multichannel marketing instruments", Information Polity, Vol. 16 No. 2, pp. 171-187.

Van Zanten, A. and Legavre, A. (2014), "Engineering access to higher education through higher education fairs", available at: https://hal-sciencepo.archiives-ouverts.fr/hal-00978898 (accessed October 12, 2017).

Wilkins, A. (2012), "School choice and the commodification of education: a visual approach to school brochures and websites", Critical Social Policy, Vol. 32 No. 1, pp. 69-86.

Yeung, K. (2017), "Hypernudge': big data as a mode of regulation by design", Information, Communication \& Society, Vol. 20 No. 1, pp. 118-136.

Zuiderent-Jerak, T. and van Egmond, S. (2015), "Ineffable cultures or material devices: what valuation studies can learn from the disappearance of ensured solidarity in health care markets", Valuation Studies, Vol. 3 No. 1, pp. 45-73.

\begin{abstract}
About the authors
Agneta Ranerup is Professor in the Department of Applied IT, University of Gothenburg. Her more recent research interests include information technology in the state-individual relationship, marketization issues and e-government. Her research has been published in various journals, including Government Information Quarterly, Electronic Markets, International Journal of Information Management, Patient Education and Counseling and Social Science Computer Review. Agneta Ranerup is the corresponding author and can be contacted at: ranerup@ituniv.se

Helle Zinner Henriksen is Associate Professor at the Department of Digitalization, Copenhagen Business School, Denmark and Adjunct Professor at the Department of Information Systems, University of Agder, Norway. Her main research interests include IT in public sector, including value of IT investments in public sector, diffusion of IT innovation and consequences of automation in public sector.
\end{abstract}

For instructions on how to order reprints of this article, please visit our website: 